\title{
PENGARUH QUANTUM LEARNING TERHADAP PENALARAN MATEMATIS SISWA SEKOLAH DASAR
}

\author{
(Eksperimen Kuasi pada Siswa Kelas IV SDN Cipaku 03 dan SDN Nangela \\ Kecamatan Paseh Kabupaten Bandung)
}

Fery Muhamad Firdaus ${ }^{1}$

\begin{abstract}
ABSTRAK
Tujuan penelitian adalah untuk mengetahui pengaruh quantum learning terhadap penalaran matematis siswa sekolah dasar. Penelitian dilakukan pada semester 2 tahun akademik 2012-2013 di Sekolah Dasar Negeri Cipaku 03 sebagai kelompok eksperimen, dan di Sekolah Dasar Negeri Nangela sebagai kelompok kontrol. Sampel penelitian yaitu 20 siswa dari masing-masing kelompok. Selama proses penelitian, kelompok eksperimen diberikan quantum learning, sedangkan kelompok kontrol diberikan pembelajaran konvensional. Pendekatan penelitian yang digunakan yaitu pendekatan kuantitatif dengan metode eksperimen kuasi desain nonequivalent groups pretest-posttests. Analisis data dilakukan dengan uji-t. Tingkat signifikansi 0,05 . Hasil penelitian menunjukkan perbedaan yang signifikan antara skor penalaran matematis siswa dari kelompok eksperimen dan kelompok kontrol. Hal ini juga menemukan bahwa quantum learning lebih efektif dalam meningkatkan penalaran matematis siswa dibandingkan dengan pembelajaran konvensional, sehingga quantum learning dapat menjadi alternatif pembelajaran yang dapat diterapkan dalam upaya meningkatkan penalaran matematis siswa sekolah dasar.

Kata Kunci: Quantum Learning, Penalaran Matematis, Pendidikan Matematika, Kelas IV, Sekolah Dasar.
\end{abstract}

\section{A. PENDAHULUAN}

Pendidikan merupakan kebutuhan seluruh umat manusia, karena melalui pendidikan manusia dapat menjadi manusia utuh dan dewasa yang diharapkan semua makhluk di muka bumi ini, karena dengan pendidikan manusia dapat mengetahui bagaimana cara memperlakukan alam dengan baik. Pendidikan yang paling utama adalah pendidikan dasar, karena pendidikan dasar merupakan proses mengembangkan kemampuan dasar manusia secara optimal dalam aspek intelektual, sosial dan personal. Selain itu, pendidikan dasar juga merupakan awal dari pemerolehan pendidikan jenjang berikutnya, hal tersebut sebagaimana telah dijelaskan dalam UU No. 2/89 Pasal 13 Ayat 1 (Surya, M. dkk. 2006:2.30) bahwa pendidikan dasar diselengarakan untuk mengembangkan sikap dan kemampuan serta memberikan pengetahuan dan keterampilan dasar dalam masyarakat serta mempersiapkan peserta didik yang memenuhi persyaratan untuk mengikuti pendidikan menengah.

Dalam pendidikan dasar, diawali dengan pendidikan di sekolah dasar (SD) yang merupakan syarat wajib mengikuti pendidikan pada jenjang yang lebih tinggi.

${ }^{1}$ Dosen STKIP Subang 
Pendidikan di SD ini sangatlah penting untuk membekali siswa untuk mempersiapkan dirinya dalam menempuh kehidupan serta mengembangkan potensi-potensi yang dimilikinya. Oleh karena itu, diharapkan pembelajaran yang dilaksanakan di sekolah dasar diharapkan dapat membekali dan mengembangkan potensi-potensi yang dimiliki siswa, baik Al-Jasad (jasmani), Al-Aql (akal) dan Ar-Ruh (rohani). Dalam potensi akal, manusia memiliki otak yang luar biasa hebatnya, dimana otak berfungsi untuk mengembangkan kemampuan penalaraan dan daya ingat manusia. Selain itu, ketika melaksanakan proses pembelajaran yang melibatkan seluruh bagian tubuh, maka otak bertindak sebagai pos perjalanan untuk setiap stimulasi yang datang ketika proses belajar.

Penalaran adalah proses penarikan kesimpulan dari sejumlah data atau keterangan yang tersedia (Windayana, et. al., 2006: 3-8). Shadiq (Karim, 2010) berpendapat bahwa seni bernalar sangat dibutuhkan di setiap segi dan setiap sisi kehidupan ini agar setiap warga bangsa dapat menunjukkan dan menganalisis setiap masalah yang muncul secara jernih; dapat memecahkan masalah dengan tepat; dapat menilai sesuatu secara kritis dan objektif; serta dapat mengemukakan pendapat maupun idenya secara runtut dan logis.

Kemampuan penalaran siswa alangkah lebih baiknya dikembangkan dalam pembelajaran di sekolah supaya siswa dapat menjadi manusia dewasa yang mampu mengambil kesimpulan dalam menyelesaikan masalah di kehidupan nyata. Pengembangan penalaran siswa ini memerlukan bantuan guru sebagai fasilitator belajar siswa, di mana guru dapat mengimplementasikan suatu desain pembelajaran yang menarik bagi siswa. Salah satu desain pembelajaran yang dapat digunakan guru dalam mengembangkan kemampuan penalaran siswa yaitu quantum learning.

Model Quantum learning merupakan suatu desain pembelajaran yang dapat mempertajam pemahaman dan daya ingat siswa, serta membuat belajar sebagai suatu proses yang menyenangkan dan bermanfaat. Pembelajaran ini mencakup aspek-aspek penting dalam program neurolinguistik (NLP), yaitu suatu penelitian tentang bagaimana otak mengatur informasi. Program ini meneliti hubungan antara bahasa dan perilaku dan dapat digunakan untuk menciptakan jalinan pengertian siswa dan guru. Para pendidik dengan pengetahuan NLP mengetahui bagaimana menggunakan bahasa yang positif untuk meningkatkan tindakan-tindakan posistif faktor penting untuk merangsang fungsi otak yang paling efektif. Semua ini dapat pula menunjukkan dan menciptakan gaya belajar terbaik dari setiap orang (De Porter dan Hernacki, 2003).

\section{B. TINJAUAN TEORITIS}

\section{Quantum Learning}

Bobbi De Porter (2007) dalam artikelnya yang berjudul The Impact of Quantum Learning (http://learningforum.com) menjelaskan pengertian Quantum Learning, sebagai berikut : "Quantum Learning is a Comprehensive model that covers both educational theory and immediate classroom implementation. Into integrates research-based best practices in education into a unified whole, making content more meaningful and relevant to students' lives. Quantum Learning is about bringing joy to teaching and learning with ever-increasing 'Aha' moment of discovery. It help teachers to present their content a 
way that engages and energizes students. This model also integrates learning and life skills, resulting in students who become effective lifelong learners-resposible for their own education".

"Quantum Learning adalah keseluruhan model yang mencakup kedua teori pendidikan dan pelaksanaan di kelas dengan cepat. Ini menggambarkan praktek dasar penelitian terpadu yang terbaik dalam pendidikan ke dalam keseluruhan, yang membuat isi lebih bermakna dan relevan bagi kehidupan siswa. Quantum Learning menjadikan mengajar dan belajar menjadi senang dengan peningkatan 'Aha' pada kegiatan penemuan. Ini membantu guru menampilkan isi mereka yang merupakan sebuah jalan yang dapat menyertakan dan memberdayakan siswa. Model ini juga memadukan belajar dan kecakapan hidup, menghasilkan siswa-siswa sebagai pebelajar yang efektif selamanya-bertanggungjawab bagi pendidikannya sendiri".

Model quantum learning berasumsi bahwa jika siswa mampu menggunakan potensi nalar dan emosinya secara jitu, maka akan mampu membuat loncatan prestasi yang tidak terduga sebelumnya. Salah satu konsep dari model ini adalah bahwa belajar itu harus mengasyikkan dan berlangsung dalam suasana gembira, sehingga pintu masuk untuk informasi baru akan lebih lebar dan terekam dengan baik oleh memori pikiran siswa. Selain itu, model quantum learning berprinsip bahwa sistem perancangan pengajaran yang efektif, efisien, dan progresif berikut metode penyajiannya untuk mendapatkan hasil belajar yang mengagumkan dalam waktu yang sedikit.

Pada prakteknya model quantum learning bersandar pada asas utama bawalah dunia mereka ke dunia kita, dan antarkan dunia kita ke dunia mereka. Dengan demikian, pembelajaran dengan model quantum learning ini merupakan kegiatan penuh kontak yang melibatkan semua aspek kepribadian siswa (pikiran, perasaan, dan bahasa tubuh) disamping pengetahuan, sikap, dan keyakinan sebelumnya, serta persepsi masa depan. Semua ini harus dikelola dengan baik sehingga mencapai harmoni (diorkestrasi).

Model quantum learning menciptakan konsep motivasi belajar, langkah-langkah menumbuhkan minat siswa, dan bagaimana siswa belajar aktif. Hal ini didasarkan pada penjelasan mengenai apa dan bagaimana unsur-unsur dan struktur otak manusia bekerja. Oleh karena itu dibuat model pembelajaran yang dapat mendorong peningkatan berbagai kecerdasan siswa. Bagaimana mengembangkan fungsi motor sensorik (melalui kontak langsung dengan lingkungan), sistem emosional-kognitif (melalui bermain, meniru, dan pembacaan cerita), dan kecerdasan yang lebih tinggi (melalui perawatan yang benar dan pengondisian emosional yang sehat). Bagaimana memanfaatkan cara berpikir dua belahan otak kiri dan kanan. Proses berpikir otak kiri yang bersifat logis, sekuensial, linear dan rasional. Proses berpikir otak kanan yang bersifat acak, tidak teratur, intuitif, dan holistik.

Quantum learning merupakan sebuah model yang menyajikan bentuk pembelajaran sebagai suatu "orkestrasi" yang jika dipilih dari dua unsur pokok yaitu: konteks dan isi. Konteks secara umum akan menjelaskan tentang lingkup lingkungan belajar baik lingkungan fisik maupun lingkungan psikhis. Sedangkan konten/isi berkenaan dengan bagaimana isi pembelajaran dikemas untuk 
disampaikan kepada siswa. Model quantum learning mengkonsep tentang "menata pentas lingkungan belajar yang tepat", maksudnya bagaimana upaya penataan situasi lingkungan belajar yang optimal baik secara fisik mapun mental. Dengan mengatur lingkungan belajar sedemikian rupa, para pelajar diharapkan mendapat langkah pertama yang efektif untuk mengatur pengalaman belajar (Sa'ud, 2010: 126).

Menurut De Porter (2003) dalam pembelajaran quantum learning ada empat ciri spesifik yang berguna untuk meningkatkan otak untuk memahami suatu informasi yang diberikan. Ciri-ciri tersebut adalah:

1. Learning To Know yang artinya belajar untuk mengetahui

2. Learning To Do yang artinya belajar untuk melakukan

3. Learning To Be yang artinya belajar untuk menjadi dirinya sendiri

4. Learning To Live Together yang artinya belajar untuk kebersamaan

Proses pembelajaran model quantum learning di SD bertujuan untuk menumbuhkan emosi positif siswa SD dengan cara menghadirkan suasana gembira saat proses pembelajaran berlangsung, menumbuhkan kekuatan otak siswa SD, menumbuhkan keberhasilan pembelajaran yang diharapkan, dan menumbuhkan kehormatan dalam diri siswa SD. Adapun karakteristik model quantum learning yaitu sebagai berikut:

1. Berpangkal pada psikologi kognitif.

2. Bersifat humanintis manusia selalu pembelajaran menjadi pusat perhatiannya, potensi diri, kemampuan pikiran, daya motivasi diyakini dapat berkembang secara maksimal atau optimal.

3. Bersifat konstruktivitas, quantum learning bersifat menekankan pentingnya peranan lingkungan dalam mewujudkan pembelajaran yang efektif dan optimal yang memudahkan dalam mencapai keberhasilan tujuan pembelajaran. Quantum learning berupaya memadukan, menyinergikan dan mengolaborasikan faktor potensi diri siswa dengan lingkungan (fisik dan mental) sebagai konteks pembelajaran.

4. Memusatkan perhatian pada interaksi yang bermutu dan bermakna bukan sekedar transaksi makna. Quantum learning memberikan tekanan pada pentingnya interaksi, frekuensi dan akumulasi interaksi yang bermutu dan bermakna yang dapat mengubah energi kemampuan pikiran dan bakat ilmiah siswa menjadi sesuatu yang bermanfaat bagi keberhasilan pembelajaran.

5. Menekankan ke alamiahan dan kewajaran proses pembelajaran, sehingga menimbulkan suasana nyaman, segar sehat, rileks, santai, menyenangkan.

6. Memiliki model yang memadukan konteks dan isi pembelajaran. Konteks pembelajaran meliputi suasana yang memberdayakan, landasan, landasan yang kukuh, lingkungan yang mengarahkan dan rancangan belajar dinamis. Isi pembelajaran meliputi suasana yang memberdaya dan rancangan pemfasilitasan yang lentur, keterampilan belajar untuk belajar, dan keterampilan hidup.

7. Memusatkan perhatian pada pembentukan keterampilan akademis, keterampilan dalam hidup dan prestasi fikal atau material. Ketiganya harus diperhatikan, diperlukan dan dikelola secara seimbang. 
8. Menginteraksi totalitas tubuh dan pikiran dalam proses pembelajaran. Aktivitas total antara tubuh dan pikiran membuat pembelajaran biasa langsung lebih nyaman dan hasilnya lebih optimal (De Porter, Reardon \& Nourie, 2005 : 6).

Model quantum learning ini memiliki keunggulan dan kelemahan manakala diterapkan pada proses pembelajaran di SD, adapun keunggulan quantum learning yaitu sebagai berikut:

1. Model quantum learning ini dapat memusatkan perhatian pada interaksi yang bermutu dan bermakna, bukan sekedar transaksi makna.

2. Pembelajaran akan bermutu dan bermakna bagi siswa karena siswa dapat belajar dengan menyenangkan.

3. Pembelajaran kuantum memusatkan perhatian pada pembentukan ketrampilan akademis, keterampilan (dalam) hidup, dan prestasi fisikal atau material.

Model quantum learning memiliki kerangka rancangan, kerangka rancangan tersebut ialah Tumbuhkan, Alami, Namai, Demontrasikan, Ulangi, Rayakan atau lebih dikenal dengan TANDUR. Adapun penjelasan tahapan kerangka rancangan tersebut yaitu sebagai berikut:

1. Tumbuhkan

Konsep tumbuhkan ini sebagai konsep operasional dari prinsip "bawalah dunia mereka ke dunia kita". Hal ini dapat dilakukan dengan cara menyertakan siswa dalam pikiran dan emosinya, sehingga tercipta jalinan dan kepemilikan bersama atau kemampuan saling memahami. Secara umum konsep tumbuhkan adalah sertakan diri siswa, pikat perhatian siswa, puaskan keingintahuansiswa, dan buatlah siswa tertarik atau penasaraan tentang materi yang akan diajarkan. Dari hal tersebut tersirat, bahwa dalam persiapan pembelajaran dimulai guru seyogyanya menumbuhkan sikap positif dengan menciptakan lingkungan yang positif, lingkungan sosial (komunitas belajar), sarana belajar, serta tujuan yang jelas dan memberikan makna pada siswa, sehingga menimbulkan rasa ingin tahu. Strategi untuk melaksanakan Tumbuhkan tidak harus dengan tanya jawab, menuliskan tujuan pembelajaran dipapan tulis, melainkan dapat pula dengan penyajian gambar/media yang menarik atau lucu, isu muthakir, atau cerita pendek tentang pengalaman seseorang.

2. Alami

Tahap alami ini berada pada kegiatan inti pembelajaran, dimana konsep alami mengandung pengertian bahwa dalam pembelajaran guru harus memberi pengalaman dan manfaat terhadap pengetahuan yang dibangun siswa sehingga menimbulkan hasrat alami otak untuk menjelajah.

Strategi konsep Alami dapat menggunakan permainan atau simulasi dengan memberi tugas secara individu atau kelompok untuk mengaktifkan pengetahuan yang telah dimiliki oleh siswa.

3. Namai

Dalam KBM konsep ini berada pada kegiatan inti, yang mana Namai disini mengandung maksud bahwa penamaan memuaskan hasrat alami otak (membuat siswa penasaran, penuh pertanyaan mengenai pengalaman) untuk 
memberikan identitas, menguatkan dan mendefinisikan. Penamaan dalam hal ini adalah mengajarkan konsep, melatih keterampilan berpikir dan strategi belajar. Strategi implementasi konsep Namai dapat menggunakan media atau alat peraga berupa gambar, susunan gambar atau gambar seri, warna, alat Bantu, kertas tulis dan poster di dinding atau yang lainnya, dengan demikian siswa akan lebih tertaik untuk mengikuti pelajaran dengan penuh motivasi untuk tahu. Pada tahap Namai ini guru bisa memuaskan keinginan siswa, guru membuat siswa penasaran, penuh pertanyaan mengenai materi yang hendak guru sampaikan. Penamaan merupakan informasi, fakta, rumus, pemikiran, tempat, dan sebagainya.

4. Demonstrasikan

Tahap Demonstrasikan ini masih pada kegiatan ini. Inti pada tahap ini adalah memberi kesempatan siswa untuk menunjukkan bahwa siswa tahu. Hal ini sekaligus memberi kesempatan siswa untuk menunjukkan tingkat pemahaman terhadap materi yang dipelajari. Strategi yang dapat digunakan adalah mempraktekkan, menyusun laporan, membuat presentasi dengan powerpoint, menganalisis data, melakukan gerakan tangan, kaki, gerakan tubuh bersama secara harmonis, dan lain-lain. Pada tahap Demonstrasikan ini guru dapat memberikan kesempatan bagi siswa untuk menyatukan penglaman mereka dengan konsep yang mereka temukan, dengan demikian konsep-konsep yang siswa temukan akan terpatri dalam memori mereka. Siswa membutuhkan kesempatan untuk merekatkan atau mengaitkan apa yang mereka pelajari dengan kehidupannya. Siswa memerlukan kesempatan untuk membuat kaitan, berlatih, dan menunjukan apa yang mereka ketahui.

5. Ulangi

Tahap ini jika kita tuangkan pada rencana pelaksanaan pembelajaran terdapat pada penutup. Tahap ini dilaksanakan untuk memperkuat koneksi saraf dan menumbuhkan rasa "aku tahu bahwa aku tahu ini". Kegiatan ini dilakukan secara multimodalitas dan multikecerdasan. Strategi untuk mengimplementasikan yaitu bias dengan membuat isian "aku tahu bahwa aku tahu ini" hal ini merupakan kesempatan siswa untuk mengajarkan pengetahuan baru kepada orang lain (kelompok lain), atau dapat melakukan pertanyaanpertanyaan post tes.

6. Rayakan

Tahap ini dituangkan pada penutup pembelajaran. Dengan maksud memberikan rasa rampung, untuk menghormati usaha, ketekunan, dan kesusksesan yang akhirnya memberikan rasa kepuasan dan kegembiraan. Dengan kondisi akhir siswa yang senang maka akan menimbulkan kegairahan siswa dalam belajar lebih lanjut. Strategi yang dapat digunakan adalah dengan pujian bernyanyi bersama, pesta kelas, memberikan reward berupa tepukan. Perayaan mmerupakan cara untuk memperkuat kesuksesan siswa dan memberi motivasi pada siswa. 


\section{Penalaran Matematis Siswa}

Penalaran matematika (mathematical reasoning) diperlukan untuk menentukan apakah sebuah argumen matematika benar atau salah dan juga untuk membangun suatu argumen matematika. Penalaran matematika tidak hanya penting untuk melakukan pembuktian (proof) atau pemeriksaan program (program verification), tetapi juga untuk melakukan inferensi dalam suatu sistem kecerdasan buatan (artifical intelligence/AI) (Suksmono, 2009: 3.1.).

Shadiq (Karim, 2010) juga berpendapat bahwa seni bernalar sangat dibutuhkan di setiap segi dan setiap sisi kehidupan ini agar setiap warga bangsa dapat menunjukkan dan menganalisis setiap masalah yang muncul secara jernih; dapat memecahkan masalah dengan tepat; dapat menilai sesuatu secara kritis dan objektif; serta dapat mengemukakan pendapat maupun idenya secara runtut dan logis.

Penalaran adalah proses penarikan kesimpulan dari sejumlah data atau keterangan yang tersedia. Dilihat dari proses penarikan kesimpulannya, penalaran dapat diklasifikasi ke dalam dua katagori yaitu penalaran induktif dan penalaran deduktif. Di mana penalaran induktif adalah penarikan kesimpulan yang didasarkan kepada sejumlah terbatas contoh, observasi/pengamatan, atau eksperimen (percobaan). Sedangkan penalaran deduktif adalah proses penarikan kesimpulan berdasarkan pernyataan-pernyataan benar, atau pernyataan-pernyataan yang dianggap benar, atau pernyataan-pernyataan yang kebenarannya telah dibuktikan (Windayana, et. al., 2006: 3-8).

Winarni dan Harmini (2011: 4) berpendapat bahwa penalaran induktif secara matematis tidak selalu benar, untuk mendapat kebenaran perlu pembuktian secara deduktif, di mana dengan penalaran deduktif aturan-aturan dalam matematika dicoba dibuktikan kebenarannya sebelum ditetapkan sebagai aturan umum. Setelah terbukti kebenarannya barulah aturan tersebut dinyatakan sah dan dapat diterapkan pada persoalan-persoalan yang istimewa sekalipun. Cara berpikir dengan cara tersebut adalah cara berpikir yang mengakui kebenaran secara umum berlaku pada hal-hal khusus.

Penalaran matematis meliputi: (1) menarik kesimpulan logis; (2) memberikan penjelasan dengan menggunakan model, fakta, sifat-sifat, dan hubungan; (3) memperkirakan jawaban dan proses solusi; (4) menggunakan pola dan hubungan untuk menganalisis situasi matematik; (5) menyusun dan menguji konjektur; (6) merumuskan lawan contoh; (7) mengikuti aturan inferensi, memeriksa validitas argumen; (8) menyusun argumen yang valid; (9) menyusun pembuktian langsung, tidak langsung dan menggunakan induksi matematika (Sari, 2009: 37).

Selain itu, dalam dokumen Peraturan Dirjen Dikdasmen No. 506/C/PP/2004 (Depdiknas, 2004) dijelaskan bahwa indikator penalaran matematis siswa yaitu sebagai berikut:

1. Menyajikan pertanyaan matematika secara lisan, tertulis, gambar dan diagram

2. Mengajukan dugaan (conjectures)

3. Melakukan manipulasi matematika

4. Menarik kesimpulan, menyusun bukti, memberikan alasan atau bukti terhadap beberapa solusi

5. Menarik kesimpulan dari pernyataan 
6. Memeriksa kesahihan suatu argumen

7. Menemukan pola atau sifat dari gejala matematis untuk membuat generalisasi.

Sementara itu, Mullis (Sukirwan, 2008: 34-35) menjelaskan bahwa penalaran matematis mencakup kemampuan menemukan konjektur, analisis, evaluasi, generalisasi, koneksi, sintesisi, pemecahan masalah tisak rutin dan justifikasi atau pembuktian. Kemampuan-kemampuan ini muncul pada saat siswa berpikir tentang suatu masalah atau penyelesaian masalah matematis. Pada saat siswa melakukan aktivitas pemecahan masalah matematis di sekolah, indikator-indikator penalaran mucul secara terkait dan saling mendukung antara kemampuan dengan kemampuan lainnya.

Adapun penjelasan mengenai indikator penelaran tersebut dapat dilihat pada tabel berikut:

Tabel 1. : Deskripsi Indikator Penalaran Matematis

\begin{tabular}{|c|c|}
\hline $\begin{array}{l}\text { Indikator } \\
\text { Penalaran }\end{array}$ & Deskripsi \\
\hline Konjektur & $\begin{array}{l}\text { Mengajukan konjektur atau dugaan pada saat meneliti pola, } \\
\text { mendiskusi ide matematis, mengajukan model, menguji kumpulan } \\
\text { data, dan membuat spesifikasi tentang suatu hasil (outcome) yang di } \\
\text { dapat dari suatu operasi atau percobaan. }\end{array}$ \\
\hline Analisis & $\begin{array}{l}\text { Menentukan dan membicarakan atau menggunakan hubungan- } \\
\text { hubungan antar variabel atau objek dalam situasi matematis, } \\
\text { menganalisis data statistik; melakukan dekomposisi gambar } \\
\text { geometri untuk menyederhanakan proses penyelesaian masalah; } \\
\text { menggambar jaringan dari suatu bangun ruang yang tidak lazim; } \\
\text { menysusun inferensi sahih dari informasi yang diberikan. }\end{array}$ \\
\hline Evaluasi & $\begin{array}{l}\text { Mendiskusikan dan mengevaluasi suatu ide matematis, konjektur, } \\
\text { strategi pemecahan masalah, metode, atau pembuktian secara kritis. }\end{array}$ \\
\hline Generalisasi & $\begin{array}{l}\text { Memperluas domain sehingga hasil pemikiran matematis atau } \\
\text { pemecahan masalah dapat diterapkan secara lebih umum atau lebih } \\
\text { luas. }\end{array}$ \\
\hline Koneksi & $\begin{array}{l}\text { Menghubungkan pengetahuan baru dengan pengetahuan yang telah } \\
\text { ada; membuat hubungan antara elemen-elemen pengetahuan } \\
\text { berbeda dengan representasi yang berkaitan; membuat hubungan } \\
\text { antara ide matematis yang berkaitan dengan objek tertentu. }\end{array}$ \\
\hline Sintesis & $\begin{array}{l}\text { Mengkombinasikan atau mengintegrasikan prosedur-prosedur } \\
\text { matematis untuk memperoleh hasil yang diinginkan; } \\
\text { mengkombinasikan beberapa hasil untuk memperoleh hasil lebih } \\
\text { jauh. }\end{array}$ \\
\hline $\begin{array}{l}\text { Pemecahan } \\
\text { masalah } \\
\text { tidak rutin }\end{array}$ & $\begin{array}{l}\text { Menyelesaikan masalah dalam konteks matematis agar kehidupan } \\
\text { sehari-hari dengan tujuan agar siswa terbiasa mengahadapi } \\
\text { masalah seupa; menerapkan suatu prosedur matematis dalam } \\
\text { konteks yang baru dihadapi. }\end{array}$ \\
\hline
\end{tabular}




\begin{tabular}{|c|l|}
\hline $\begin{array}{c}\text { Jastifikasi } \\
\text { atau }\end{array}$ & $\begin{array}{l}\text { Menyajikan bukti validasi suatu aksi atau kebenaran suatu } \\
\text { pernyataan dengan berpedoman pada hasil atau sifat-sifat }\end{array}$ \\
pembuktian & $\begin{array}{l}\text { matematis yang diketahui; mengembangkan argumen matematis } \\
\text { untuk membuktikan atau menyangkal suatu pernyataan. }\end{array}$ \\
\hline
\end{tabular}

\section{Sumber :}

(Sukirwan, 2008: 34-35)

\section{METODE PENELITIAN}

Pendekatan penelitian yang digunakan yaitu pendekatan kuantitatif, hal tersebut dikarenakan penelitian ini mengontrol bagaimana kelompok subjek penelitian diperlakukan dan kemudian mengukur bagaimana tindakan mempengaruhi setiap kelompok, sehingga diperlukan penelitian kuantitatif.

Metode yang digunakan dalam penelitian ini adalah eksperimen kuasi, hal ini dikarenakan penelitian dilaksanakan dengan maksud untuk mempelajari sesuatu dengan mengubah suatu kondisi dan mengamati pengaruhnya terhadap hal lain. Penelitian eksperimen kuasi yang akan dilaksanakan yaitu dengan bentuk nonequivalent groups pretest-posttets design yang mengacu kepada pendapat Fraenkel dan Wallen (2007:278).

Yang menjadi populasi dari penelitian ini adalah seluruh siswa kelas IV SDN Cipaku 03 dan SDN Nangela Kecamatan Paseh Kabupaten Bandung. Setiap masingmasing kelas diambil jumlah siswa yang sama sebagai sampel, yaitu sebanyak 20 siswa. Penempatan sampel pada kelompok eksperimen dan kelompok kontrol tidak dilakukan secara random atau acak, tetapi dilaksanakan secara non random.

Instrumen penelitian yang digunakan yaitu pedoman observasi dan lembar tes evaluasi penalaran matematis siswa pada konsep volume kubus dan balok. Pembuatan pedoman observasi pelaksanaan quantum learning pada kelompok eksperimen, dan pembuatan pedoman observasi pelaksanaan pembelajaran konvensional pada penelitian di kelompok kontrol. Kegiatan evaluasi tes penalaran matematis siswa dilakukan dalam rangka mengetahui dan mengidentifikasi penalaran matematis siswa mengenai bahan ajar yang sedang dibelajarkan, di mana pelaksanaan evaluasi dalam penelitian ini bertujuan untuk mengukur penalaran matematis siswa mengenai materi bangun ruang dan kaitannya dengan bangun datar. Pengembangan instrumen dilakukan dengan cara pengujian validitas, pengujian reliabilitas, perhitungan daya pembeda dan perhitungan taraf kesukaran.

Analisis data hasil tes dimaksudkan untuk mengetahui pengaruh quantum learning dalam meningkatkan penalaran matematis siswa kelas IV sekolah dasar mengenai konsep bangun ruang dan kaitannya dengan bangun datar. Teknik analisis data yang digunakan pada penelitian ini yaitu teknik statistik inferensial parameter, di mana teknik ini dilaksanakan dengan menggunakan uji t, taraf signifikansi 0,05.

Penelitian dengan menggunakan metode quasi experimental design bentuk nonequivalent groups pretest-posttets design ini dilaksanakan dengan prosedur pelaksanaan penelitian sebagai berikut: Pertama, perencanaan dan persiapan penelitian, dimana pada proses ini dimulai dengan mendefinisikan masalah penelitian, mencari bahan rujukan, dan membuat hipotesis penelitian, menentukan desain penelitian, kemudian memilih sampel dari populasi tertentu sesuai dengan 
desain penelitian yang telah dipilih, serta membuat Rencana Pelaksanaan Pembelajaran (RPP) quantum learning dan instrumen-instrumen yang digunakan ketika penelitian. Kedua, pelaksanaan penelitian, di mana pelaksanaan penelitian ini dilakukan dengan penempatan sampel pada kelompok eksperimen dan kelompok kontrol, memberi pretes masing-masing kelompok, didasarkan pada variabel dependent, mengatur kondisi perlakuan terhadap kelompok eksperimen bukan kepada kelompok kontrol, dan melakukan perlakuan atau treatment pelaksanaan quantum learning terhadap kelompok eksperimen, dan pembelajaran konvensional terhadap kelompok kontrol, serta masing-masing kelompok diberi posttes sesuai dengan variabel dependent. Ketiga, pengumpulan data dan analisis data yang telah diperoleh. Keempat, membuat laporan penelitian.

\section{HASIL PENELITIAN}

Hasil uji-t kreativitas matematis pada saat pretes yaitu bahwa nilai signifikansi (P-value) untuk faktor pembelajaran sebesar $0,756 \geq 0,05$ maka $\mathrm{H}_{0}$ diterima. Dengan kata lain, tidak terdapat perbedaan rerata skor pretes kreativitas matematis siswa antara kelompok kontrol dan kelompok eksperimen berdasarkan faktor pembelajaran. Akan tetapi, hasil uji perbedaan rerata posttes kreativitas matematis siswa yaitu bahwa nilai signifikansi (P-value) untuk faktor pembelajaran sebesar 0,000 < 0,05 maka $\mathrm{H}_{0}$ ditolak. Dengan kata lain, terdapat perbedaan rerata skor posttes kreativitas matematis siswa antara kelompok kontrol dengan kelompok eksperimen. Adapun hasil perhitungan uji perbedaan rerata dapat dilihat pada tabel 5 berikut ini.

Tabel 5

Tabel Hasil Pengujian Perbedaan Rerata Kreativitas Matematis Siswa

\begin{tabular}{|c|c|c|c|c|c|c|c|}
\hline Tes & Pembelajaran & Perbedaan & $T_{\text {hitung }}$ & Df & $t_{\text {tabel }}$ & Sig. & $\mathrm{H}_{0}$ \\
\hline Pretes & $\begin{array}{c}\text { Eksperimen- } \\
\text { Kontrol }\end{array}$ & $5,15<5,23$ & 0,313 & 38 & 2,024 & 0,756 & Diterima \\
\hline Posttes & $\begin{array}{c}\text { Eksperimen- } \\
\text { Kontrol }\end{array}$ & $8,28>7,18$ & $-6,308$ & 38 & 2,024 & 0,000 & Ditolak \\
\hline
\end{tabular}

Jika dilihat dari tabel 5 di atas, rata-rata skor pretes kemampuan penalaran matematis siswa kelompok eksperimen dan kontrol masing-masing adalah adalah 5,15 dan 5,23. Berdasarkan hasil uji perbedaan rata-rata diperoleh bahwa rata-rata kedua kelompok tersebut tidak memiliki perbedaan yang signifikan. Dalam hal ini dapat disimpulkan bahwa kemampuan awal penalaran matematika siswa kelompok eksperimen dan kelompok kontrol adalah sama.

Setelah dilakukan treatment (perlakuan) terhadap kelompok eksperimen dengan menggunakan quantum learning dan kelompok kontrol dengan menggunakan pembelajaran konvensional sebanyak tujuh treatment pada masingmasing kelas, maka diperoleh rata-rata skor postes kelompok eksperimen adalah 8,28 dan kelompok kontrol adalah 7,18. Dengan memperhatikan rata-rata skor posttes antara kelompok eksperimen dan kelompok kontrol dapat disimpulkan 
bahwa kemampuan penalaran matematis kelompok eksperimen lebih baik daripada kelompok kontrol secara signifikan.

Rerata skor pretes siswa kelompok eksperimen $(5,15)$ dan kelompok kontrol $(5,23)$ relatif sama. Hal tersebut ditunjukkan oleh perbedaan rerata yang hanya 0,08. Namun rerata skor posttes siswa kelompok eksperimen $(8,28)$ dan kelompok kontrol $(7,18)$ berbeda sebesar 1,10 . Kenaikan rerata skor posttes dari skor pretes kelompok eksperimen 3,13, dan kenaikan rerata skor posttes dari skor pretes kelompok kontrol hanya 1,95 .

Hal tersebut memberikan asumsi bahwa kualitas peningkatan penalaran matematis siswa kelompok eksperimen lebih baik. Untuk lebih jelasnya, berikut diagram yang menunjukkan perbandingan penalaran matematis kedua kelompok dilihat dari rata-rata hasil pretes-posttes.

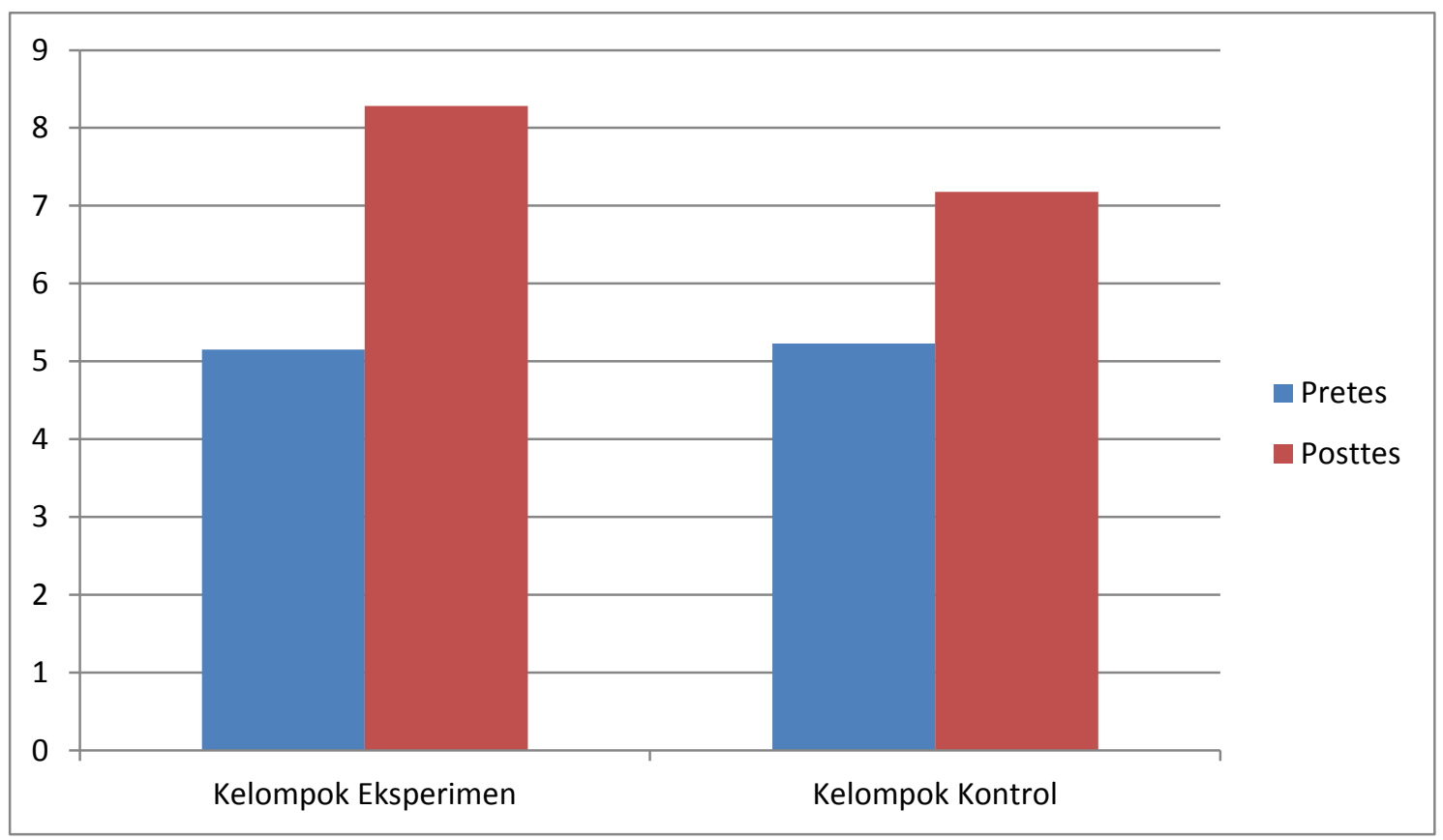

\section{Diagram 1 \\ Perbedaan Penalaran Matematis Kelompok eksperimen dan Kelompok kontrol}

Hasil Uji signifikansi terhadap perbedaan rerata skor postes kelompok eksperimen dengan rerata skor postes kelompok kontrol diperoleh bahwa, dalam tingkat keberartian $\alpha=0,05$ secara meyakinkan terdapat perbedaan yang signifikan antara rerata skor postes kelompok eksperimen dengan rerata skor posttes kelompok kontrol. Peningkatan rerata hasil kemampuan penalaran siswa kelas ekperimen lebih besar daripada rerata hasil kemampuan penalaran siswa kelompok kontrol, sehingga dapat diketahui bahwa quantum learning lebih berpengaruh secara signifikan daripada pembelajaran konvensional dalam meningkatkan kemampuan penalaran siswa sekolah dasar. 


\section{E. KESIMPULAN}

Sejalan dengan rumusan masalah dan pertanyaan penelitian, studi ini memperoleh kesimpulan yang berkenaan dengan hasil studi empirik tentang eksperimen quantum learning dalam meningkatkan penalaran matematis siswa kelas IV sekolah dasar. Berdasarkan hasil penelitian yang diperoleh, maka dapat diambil kesimpulan bahwa quantum learning lebih efektif dalam meningkatkan penalaran matematis siswa dibandingkan pembelajaran konvensional, hal ini ditandai dengan terdapatnya perbedaan rerata skor posttes penalaran matematis siswa antara kelompok eksperimen yang menggunakan quantum learning dengan kelompok kontrol yang menggunakan pembelajaran konvensional. Kemampuan penalaran matematis siswa yang memperoleh pembelajaran quantum learning lebih baik daripada siswa yang memperoleh pembelajaran konvensional. Selain itu, siswa pada kelompok eksperimen memberikan respon yang baik dan merasa senang terhadap pembelajaran quantum learning. Sehingga quantum learning dapat dijadikan alternatif yang efektif dalam meningkatkan kemampuan penalaran matematis siswa sekolah dasar.

\section{DAFTAR PUSTAKA}

Depdiknas (2004). Peraturan Dirjen Dikdasmen No. 506/C/PP/2004 tanggal 11 November 2004 tentang Penilaian Perkembangan Anak Didik Sekolah Menengah (SMP). Jakarta: Ditjen Dikdasmen Depdiknas.

De Porter, B. (2007). Quantum Learning Network. [online]. Tersedia: http:/ /learningforum.com. [9 Februari 2011]

De Porter, B. \& Hemacky, M. (2003). Quantum Learning: Membiasakan Belajar Nyaman dan Menyenangkan. Bandung: Kaifa.

De Porter, B., Reardon, M., \& Nourie, S. S. (2005). Quantum Teaching: Mempraktekkan Quantum Learning di Ruang - Ruang Kelas. Bandung: Kaifa.

Fraenkel, J. R. dan Wallen, N. E. (2007). How to Design and Evaluate Research in Education. New York: Mcgraw hill.

Karim, A. (2010). Meningkatkan Kemampuan Penalaran dan Berpikir Kritis Matematis Siswa SMP Melalui Pembelajaran Model Reciprocal Teaching. Tesis Magister SPS UPI Bandung: tidak diterbitkan.

Sa'ud, U. S. (2010). Inovasi Pendidikan. Bandung: Alfabeta.

Sari, A. (2009). Pemberdayaan Benda Manipulatif dalam Pembelajaran Matematika untuk Meningkatkan Kemampuan Pemahaman dan Penalaran Siswa Sekolah Dasar. Tesis Magister pada Pendidikan Dasar UPI Bandung: tidak diterbitkan.

Sukirwan. (2008). Kegiatan Pembelajaran Eksploratif untuk Meningkatkan Kemampuan Penalaran dan Koneksi Matematis Siswa Sekolah Dasar. Tesis Magister pada Pendidikan Dasar UPI Bandung: tidak diterbitkan.

Suksmono, A. B. (2009). Matematika Diskrit dan Aplikasina. Bandung: Institut Teknologi Bandung.

Surya, M. dkk. (2006). Kapita Selekta Kependidikan SD. Jakarta : Penerbit Universitas Terbuka.

Winarni, E. S. dan Harmini, S. (2011). Matematika untuk PGSD. Bandung: Rosda. Windayana, H. et. al. (2006). Konsep Dasar Matematika. Bandung: UPI Kampus Cibiru. 